\title{
Crude Oil Price and Exchange Rate Nexus: An Ardl Bound Approach
}

\author{
Kabiru Saidu Musa1*, Rabiu Maijama'a1,2, Nafisa Muhammed1,3, Asma'u Usman ${ }^{1,4}$ \\ ${ }^{1}$ M.Sc. Economics Students, Bauchi State University Gadau, Yuli Campus, Bauchi State, Nigeria \\ ${ }^{2}$ NNPC Retail Sales Representative, Nigeria National Petroleum Corporation, NNPC Tower, Central Business District, PMB 190, \\ Garki, Abuja, Nigeria \\ ${ }^{3}$ Central Bank of Nigeria (CBN) Gombe Branch, Gombe State, Nigeria \\ ${ }^{4}$ Federal Radio Corporation (FRC) Bauchi Branch, Bauchi, Nigeria \\ Email: ${ }^{\star k a b i r u s a i d u m u s a @ g m a i l . c o m ~}$
}

How to cite this paper: Musa, K.S., Maijama'a, R., Muhammed, N. and Usman, A. (2020) Crude Oil Price and Exchange Rate Nexus: An Ardl Bound Approach. Open Access Library Journal, 7: e6072.

https://doi.org/10.4236/oalib.1106072

Received: January 13, 2020

Accepted: March 7, 2020

Published: March 10, 2020

Copyright $\odot 2020$ by author(s) and Open Access Library Inc.

This work is licensed under the Creative Commons Attribution International License (CC BY 4.0).

http://creativecommons.org/licenses/by/4.0/

\begin{abstract}
This study investigates the impact of crude oil price on exchange rate in $\mathrm{Ni}$ geria using an autoregressive distributed lag (ARDL) model covering the period from 1983-2017. The results showed that crude oil price has negative and significant impact on exchange rate in both the long run and the short run whereas oil revenue and Gross Domestic Products have significant positive impact on exchange rate also in both the long-run and the short-run periods. The findings suggested that crude oil price which is the focal point of the study, could affect exchange rate in the both the long-run and the short-run. Therefore the study concludes that crude oil price, oil revenue and Gross domestic Products are among the determinants of exchange rate in Nigeria.
\end{abstract}

\section{Subject Areas}

Socioeconomics

\section{Keywords}

Crude Oil Price, Exchange Rate, GDP, Oil Revenue, ARDL Approach and VECM Granger Causality

\section{Introduction}

Crude oil as an energy source since its discovery in the 1800s has been vitally important to the world economy [1]. The importance of oil has been raised to the extent that in a world suddenly without oil, all the major distribution systems that allow economic transactions on a more than local basis would fail and 
the world collapsed [2].

The impact of exchange rate volatility on actual activities has been an issue to widespread debate among economists. This exchange rate fluctuation can be looked into two main ways; these are the demand side and supply side. On the demand side, there has been a general idea that depreciation or devaluation of the currency could increase production when the country encourages net export component. Thus, when the country decides to export more its products to the international market. On the supply side, the channels of interaction of exchange rate and macro economy have made its more complicated for policy makers of various countries more especially those that are importer of goods and services like Nigeria [3].

Exchange rate fluctuation is a threat to developing economies in term of financing its national budgets to meet the demand of the people. This volatility in exchange rate is normally explained by economic factors such as inflation rate, balance of payments and interest rate [4].

The relationship between oil prices and economic activities has been a subject of discussion in the recent times, as changes in crude oil price affect domestic oil prices which in turn affect virtually everything in the country thereby reduce the standard of living of the people. Volatility in exchange rate is seen as a common phenomenon among economies which cause negative effect on international trade among developing countries as bilateral trade is endangered by threats involved. Economists are of great extent concerned in finding the cause of the factors exchange rate movements which create discomfort among the populace [5].

Shock in crude oil prices has adversely affected the oil exporting countries like Nigeria, especially in the areas of foreign exchange earnings, foreign reserves, decline in government revenue and threat in terms of ability to meet financial obligations as at when due. The average crude oil price further dropped in a row by USD8.26 or 13.10\% month to month USD54.77 per barrel in December 2018; the lowest since October 2017. This decrease is due to concern over unforeseen rise in global oil supply with decreased demand amidst ambiguity about worldwide economic growth [6].

The exchange rate of the Naira was relatively stable between 1973 and 1979, during the oil boom (regulatory era). This was also the situation prior to 1970, when agricultural products accounted for more than $70 \%$ of the nation's gross domestic product (GDP) [7]. However, as a result of the deployment in the petroleum oil sector, in 1970's the share of agriculture I total exports declined significantly, while that of oil increased. However, from 1981, the world oil market started to deteriorate and its economic crises emerged in Nigeria because of the country's dependence on oil sales for her export earnings. Since the Nigerian has remained import-dependence on oil-supported, the fluctuation of oil prices would have effect on Nigeria's oil revenue (i.e. major source of income) [8]. Thus this research is faced with determining whether the crude oil price has any bearing in the exchange rate in Nigeria and other macroeconomic variables. 
The significance of the study cannot be overemphasized. Firstly, the research will help to inform the decision makers on the nature of impact of crude oil price on exchange rate in the oil exporting country like Nigeria. Secondly, the research will serve as a contribution to the literature as well as to the methodology. Thirdly, the empirical finding of the paper will be of great importance to the government, to the private oil companies and the academy as a whole.

The objective of this research is to look at the impact of crude oil price on exchange rate in Nigeria. Therefore, this research intended to add to the literature on the impact of crude oil price on exchange rate by employing an autoregressive distributed lag (ARDL) bound approach advanced by Pesaran, Shin and Smith (2001).

This research is organized in sections. The first section contains introduction, the research problem, the significance of the study, the objective of the study and the organization of the paper. The second section consists of review of related literature, which provides some evidence from around the world and evidence from Nigeria. The third section presents the research methodology and the data. The fourth section presents results and discussion of the findings. Finally, the fifth section discusses the conclusions and the policy recommendations.

\section{Literature Review}

Exchange rate and crude oil price are important research variables in recent times; both generate significant impact on macro-economic variables like unemployment, interest rate, inflation, international trade and above all economic growth. The linkage between them has gained great importance in literature since the first oil shock in 1973/1974, when alots of developing countries moved to floating exchange rate from fixed exchange rate by adopting structural adjustment program (SAP). The enormous literature tries to link crude oil prices to real exchange rates of developing and developed economies [9].

\subsection{Evidence from around the World}

[10] investigated the impact of crude oil price changes on foreign exchange rate of Indian rupee relative to a dollar. The study developed a monetary theory of exchange rate determination that incorporates real domestic GDP and foreign GDP, real domestic crude oil price and interest rate differentials. The study employed error correction model (ECM) on quarterly data from 1996 to 2012. The estimated results revealed that domestic real money balances, domestic real GDP, and foreign real GDP are determinants of real exchange rate in India.

[11] investigated crude oil price on and exchange rate nexus in Thailand. The study employed monthly data between July 1997 to December 2013 and used co-integration and bi-variate GARCH technique of analysis. The result of the study revealed that no co-integration and causality between the two variables but rise in volatility of crude oil price prompt real foreign exchange rate volatility to also rise. 
[12] studied the impacts of oil price shocks on gross domestic product (India, Russia, Brazil and China) 1987 to 2014. Show that the oil price has a positive relationship with GDP. The oil price increase has a negative relationship with gross domestic product in the China and Indian and on the other side the positive coefficient values of Russia and Brazil the positive impact of oil price increase on GDP.

[13] studied exchange rate volatility and real oil price fluctuation nexus in $\mathrm{Pa}$ kistan. The study used Johansen co-integration and vector error correction model (VECM) on quarterly date from 1983: Q1 to 2014: Q2. The results of the study revealed that real foreign reserves, real exports, productivity differential, interest rate differential and crude oil prices are important variables that determine exchange rate while real crude oil price volatility, consumer price index volatility and real foreign reserves volatility have positive effect on real foreign exchange rate volatility respectively.

[14] worked on the impact of Oil Price on economic growth in Iraq. To achieve the stated objective, the study adopted ordinary least squares approach, and the secondary data was used for the period of 2000 to 2015 and multiple regressions with its assumption were used in order to analyze the data. The findings showed that oil price and oil export were very important determinants of economic growth in Iraq and exchange variables has no impact on the participants of increasing the economic growth because of having corruption in public banks in Iraq.

[15] studied the degree of interdependence between oil price shocks and economic growth for (United Arab Emirates, Kuwait, Saudi Arabia and Venezuela) in OPEC during the period from 2000 to 2010 . They used co-integration test, the result revealed that oil price shock short-term and medium-term during the period of fluctuations in financial turmoil and the global business cycle impact on economic growth in organization of the petroleum exporting countries. Although, the effect of the medium-term effects is greater than that of the short-term effects.

\subsection{Evidence from Nigeria}

[16] examined the impact of crude oil price volatility on macroeconomic activities in Nigeria. The study employed lag augmented VAR models, EGARCH and impulse response function. The study used secondary data covering the period of 1970 to 2009. The study revealed that there is unidirectional causality between real exchange rate, interest rate and crude oil price. The causality runs from crude oil price to interest rate and foreign exchange rate. Conversely, no significant relationship was discovered among crude oil price and GDP.

[17] provided a quantitative analysis to the impact of fluctuations in oil prices on the Nigerian economy. They apply the General Method of moment (GMM) to estimate the effect of positive and negative surges of oil price using data that covers the period between 1981 and 2010 during which Nigeria has experienced 
increasing rates of oil exports. Their findings confirm the positive impact of oil price increases on Nigerian oil exporting economy. Yet the negative impact is represented by the uncertainty that such surges create regarding the expected revenue of oil exports.

[18] empirically examined the link between exchange rates and crude oil prices in Nigeria. The study was carried out to know if there is positive relationship between exchange rate and oil prices as revealed by the findings of previous research and if crude oil prices can be responsible for long run exchange rate movement. The study makes used of quarterly data from 1981: Q1 to 2009: Q4 and error correction model (ECM). It was revealed that movements in exchange rate were caused by changes in permanent components and that oil price volatility does not have effect on exchange rate in the short-run. The study therefore concludes that this may be because crude oil does not price in Naira.

[19] examined the impact of oil price volatility on the real exchange rate in Nigeria using quarterly data from the first quarter of 1981 to the fourth quarter of 2009 by employing co-integration and error correction model (ECM). The results of the study show that dynamic short-run impact of oil price volatility on exchange rate does not hold, even though most of the movement in real exchange rate is due to changes in the long-run.

[20] investigated the crude oil price and foreign exchange rate causality in $\mathrm{Ni}$ geria. The study used monthly data from 2008 to 2014. The study used ordinary least squares (OLS) and VAR model, the result revealed that crude oil price significantly affects exchange rate compared to imports. It also showed unidirectional causality from crude oil prices to exchange rates and from crude oil prices to foreign reserve exist. The study concluded that Nigeria should change her structure of international trade to reduce import dependence and enable monetary authorities to manage both her foreign reserves and exchange rate.

[21] in their study from 1986 to 2015 on crude oil prices and economic growth of Nigeria adopted Vector Error Correction Model (VECM) on the secondary data. The results revealed that a positive and unidirectional relationship that runs from crude oil price to GDP growth rates and conclude that crude oil price exerts positive influence on the economic growth of Nigeria.

[22] studied the impact of crude oil price and exchange rate on economic growth of Nigeria using secondary data from 1982 to 2018 by employing autoregressive distributed lag (ARDL) model. The findings of the study revealed that crude oil price and exchange rate have significant positive impact on economic growth in both the short run and long run periods. The researchers recommend for the diversification of the Nigeria economy in order to reduce heavy reliance on crude oil.

[23] examined the relationship between oil price and economic growth in $\mathrm{Ni}$ geria using annual time series data for the period 1974 to 2014. Using Granger causality test the findings revealed that there is no long run relationship among the variables. In addition, there is a significant positive unidirectional causality 
running from oil price to economic growth and also from oil price to total exports. They recommend stability in oil price to achieve high economic growth in the short run. Substantial amount of government budgetary allocation should be directed towards educational sector in order to strengthen economic growth through human capital in the short run. And measures to maintain higher oil price and stability in the world market should be adopted so as to increase the volume of oil export which will eventually lead to increase in total export.

Evidence from around the world and evidence from Nigeria shows that the relationship between the crude oil price and foreign exchange rate is documented and got mixed [positive and negative results] which are confirmed in the literatures. In this circumstance, a research gap about the relationship between foreign exchange rate and crude oil price in Nigerian context is formulated. Therefore, this study fills the gap using ARDL approach on annual time series data of Nigeria from 1983-2017.

\section{Methodology and Data}

The study used a time series data in investigating the connection between crude oil prices, oil revenue and gross domestic product on exchange rate. The data was obtained from secondary source; the Brent crude oil prices from Energy Information Administration (EIA) and Central Bank of Nigeria (CBN), exchange rate (US dollar per LCU) and Economic Growth (GDP per capita Constant US\$ 2010) from World Development Indicators of World Bank (WDI) while Oil revenue from the Central Bank of Nigeria (CBN) Statistical Bulletin 2018 for the period of 1983 to 2017 were used for the analysis. Crude oil prices, oil revenue and economic growth are the independent variables. And exchange rate is modeled as a dependent variable.

This study employs Autoregressive Distributed Lag (ARDL) approach to co-integretion profounded by Pesaran (1997) and further modified and developed by Pesaran, Shin and Smith $(1999,2000)$ and also by Narayan $(2005)$. This study adopted ARDL approach because of its comparative superiority over other approaches to co-integration this is because they require variables to be stationary at first difference, i.e. integrated of order I (1). However, ARDL was developed to accommodate such circumstance. It can be used to analyses the data even if they are at different orders of integration. Additionally, it can also determine both the short run and long run co-integration among the variables of the study.

\subsection{Model Specification}

It should be noted that this study involves a multi-variate analysis, that is involved four variables namely crude oil price, exchange rate, gross domestic products and oil revenue. Since the study is trying to examine the impact of crude oil price on exchange rate within the context of the Nigerian economy during the period under study, we have limited the number of variable to crude 
oil price, exchange rate, gross domestic products and oil revenue only, otherwise adding any variable may influence the result. To derive the model, it is known that based on the Quantity theory of money equation (particularly income approach equation) where demand for money is equated to the supply of money. Therefore, the equation can be denoted as follow: $M V=P Y$

$$
P=\frac{M V}{Y}=f\left(M V Y^{-1}\right)
$$

where: $P$ is the crude oil price, $M$ will be replaced with oil revenue, $V$ will be replaced with exchange rate and $Y^{-1}$ will be replaced with economic growth. Therefore, the model can be written as: $E X C=f(O R E V, C O P, G D P C)$.

Following the above model of the study, the econometric form of the model can be written in a simple log-linear form and augmented it with the crude oil price and exchange rate variables as follows:

$$
\ln E X C_{t}+\beta_{0}+\beta_{1} \ln O R E V_{t}+\beta_{2} \ln C O P_{t}+\beta_{3} \ln G D P C_{t}+v_{t}
$$

where: $\ln E X C_{t}$ is the natural log of exchange rate, $\ln O R E V_{t}$ is the natural $\log$ of oil revenue, $\ln C O P_{t}$ is the natural $\log$ of Crude oil price, $\ln G D P C_{t}$ stand in for the natural log of GDP per capita and $v_{t}$ is the error term.

\subsection{ARDL Bounds Test for Co-Integration}

$$
\Delta z_{t}=\beta_{0}+\sum_{i=1}^{k} \beta_{i} \Delta z_{t-i}+\sum_{i=0}^{k} \beta_{i} \Delta x_{t-i}+\sum_{i=0}^{k} \beta_{i} \Delta y_{t-i}+\alpha_{1} z_{t-i}+\alpha_{2} x_{t-i}+\alpha_{3} y_{t-i}+\varepsilon_{t}
$$

The optimum lag is chosen by the Akaike Information Criteria (AIC) and Schwarzt Bayesia Criterion (SBC). For small sample size, compare the F-statistics with the critical bounds by Narayan (2005) for large sample Pesaran et al. (2001).

\subsubsection{Estimation of the Long Run Coefficients}

$$
z_{t}=\beta_{1}+\sum_{i=1}^{k} \beta_{i} z_{t-i}+\sum_{i=0}^{k} \beta_{i} x_{t-i}+\sum_{i=0}^{k} \beta_{i} y_{t-i}+\varepsilon_{t}
$$

To conclude for the existence of long run relationship, we use the Wald test coefficient.

\subsubsection{Estimation of the Short Run Coefficients}

$$
\Delta z_{t}=\beta_{0}+\sum_{i=1}^{k} \beta_{i} \Delta z_{t-i}+\sum_{i=0}^{k} \beta_{i} \Delta x_{t-i}+\sum_{i=0}^{k} \beta_{i} \Delta y_{t-i}+\vartheta E C T_{t-i}+\varepsilon_{t}
$$

$\vartheta$ is the speed of adjustment coefficient. The following ARDL model is provided to test the relationship between crude oil price and exchange rate. Therefore, the model is specified in three parts. The first part is the co-integration, the second part is the long run model and the third part is the short run model.

\section{ARDL Co-integration model}

To test for co-integration between the variables of the model equation below 
is specified and estimated using ARDL bound test for co-integration. The model was specified together with the null and alternative hypothesis which may be rejected or failed to be rejected. This stands a turning point when the null hypothesis of no co-integration between variables of the model is failed to be rejected, then try another method such as vector error correction model (VECM) and others. If co-integration relationship exists by rejecting null hypothesis we proceed to estimate short run coefficients. Thus, the specified model for co-integration is as follows:

$$
\begin{gathered}
\Delta \ln E X C_{t}=\beta_{0}+\sum_{i=1}^{k} \beta_{1 i} \Delta \ln E X C_{t-i}+\sum_{i=0}^{k} \beta_{2 i} \Delta O R E V_{t-i}+\sum_{i=0}^{k} \beta_{3 i} \Delta C O P_{t-i} \\
+\sum_{i=0}^{k} \beta_{4 i} \Delta G D P C_{t-i}+\alpha_{1} E X C_{t-i}+\alpha_{2} O R E V_{t-i}+\alpha_{3} \operatorname{COP}_{t-i}+\alpha_{4} G D P C_{t-i}+\varepsilon_{t} \\
H_{0}: \alpha_{1}=\alpha_{2}=\alpha_{3}=\alpha_{4}=0 \text { (No Co-integration) } \\
H_{1}: \alpha_{1} \neq \alpha_{2} \neq \alpha_{3} \neq \alpha_{4} \neq 0 \text { (Co-integration exists) }
\end{gathered}
$$

\section{ARDL Long run model}

Having existed co-integration between the variables of the model we can proceed to estimate the long run coefficients. To test the long run coefficients, equation 6 below is specified and estimated to obtain the coefficient of the long run.

$$
\begin{aligned}
\ln E X C_{t}= & \alpha_{0}+\sum_{i=1}^{k} \alpha_{1 i} \ln E X C_{t-i}+\sum_{i=0}^{k} \alpha_{2 i} \operatorname{OREV}_{t-i}+\sum_{i=0}^{k} \alpha_{3 i} \operatorname{COP}_{t-i} \\
& +\sum_{i=0}^{k} \alpha_{4 i} G D P C_{t-i}+\varepsilon_{t}
\end{aligned}
$$

\section{ARDL short run and error correction model:}

To estimate the short run coefficients and error correction term which measure the speed of adjustment or convergence the equation 7 below was specified and estimated.

$$
\begin{aligned}
\Delta \ln E X C_{t}= & \beta_{0}+\sum_{i=1}^{k} \beta_{1 i} \Delta \ln E X C_{t-i}+\sum_{i=0}^{k} \beta_{2 i} \Delta O R E V_{t-i}+\sum_{i=0}^{k} \beta_{3 i} \Delta C O P_{t-i} \\
& +\sum_{i=0}^{k} \beta_{4 i} \Delta G D P C_{t-i}+\vartheta E C T_{t-1}+\varepsilon_{t}
\end{aligned}
$$

Robustness Check Using Dynamic Ordinary Least Squares (DOLS) Fully Modified Ordinary Least Squares (FMOLS) and Canonical Co-integration Regression (CCR)

To gauge the long-run estimate, we apply Dynamic Ordinary Least Square (DOLS), Fully Modified Ordinary Least Square (FMOLS) and Canonical Co-integration Regression (CCR). DOLS and FMOLS have the power to deal with endogeneity problem, simultaneity bias and small sample bias. These estimators are good for robustness check of ARDL estimates. DOLS and FMOLS have been advanced by Stock and Watson (1993) and Philip and Moon (1999), while CCR was advanced by Park (1992) respectively to address the problem of serial correlation and small sample bias attributed to Ordinary Least Squares 
(OLS) estimator. The estimators can also be applied to mix order of integrated variables in co-integration framework. Considering the strengths of these estimators, their results will serve as robustness checks to ARDL long-run test results.

\section{Vector Error Correction Model (VECM) Granger Causality}

Having found co-integration between variables, the direction of causality between the variables is examined using VECM. [24] maintained that VECM is suitable for analyzing causality between variables of interest when the variables are co-integrated. Equally, the methodology is suitable for causality between variables of the same order, that is, when they are integrated of order one i.e. I (1). The VECM modeling framework within a system of error correction model for this study is as follows:

$$
\begin{aligned}
{\left[\begin{array}{l}
\Delta \ln E X C_{t} \\
\Delta \ln E X C_{t} \\
\Delta \ln E X C_{t} \\
\Delta \ln E X C_{t}
\end{array}\right]=} & {\left[\begin{array}{l}
\beta_{1} \\
\beta_{1} \\
\beta_{1} \\
\beta_{1}
\end{array}\right]+\left[\begin{array}{llll}
c_{11 p} & c_{12 p} & c_{13 p} & c_{14 p} \\
c_{21 p} & c_{22 p} & c_{23 p} & c_{24 p} \\
c_{31 p} & c_{32 p} & c_{33 p} & c_{34 p} \\
c_{41 p} & c_{42 p} & c_{43 p} & c_{44 p}
\end{array}\right] \times\left[\begin{array}{l}
\Delta \ln E X C_{t-1} \\
\Delta \ln E X C_{t-1} \\
\Delta \ln E X C_{t-1} \\
\Delta \ln E X C_{t-1}
\end{array}\right]+\cdots } \\
& +\left[\begin{array}{llll}
c_{11 q} & c_{12 q} & c_{13 q} & c_{14 q} \\
c_{21 q} & c_{22 p} & c_{23 q} & c_{24 q} \\
c_{31 q} & c_{32 q} & c_{33 q} & c_{34 q} \\
c_{41 q} & c_{42 q} & c_{43 q} & c_{44 q}
\end{array}\right] \times\left[\begin{array}{l}
\Delta \ln E X C_{t-1} \\
\Delta \ln E X C_{t-1} \\
\Delta \ln E X C_{t-1} \\
\Delta \ln E X C_{t-1}
\end{array}\right] \\
& +\left[\begin{array}{l}
\gamma_{1} \\
\gamma_{2} \\
\gamma_{3} \\
\gamma_{4}
\end{array}\right]\left(E C M_{t-1}\right)+\left[\begin{array}{l}
\eta_{1 t} \\
\eta_{2 t} \\
\eta_{3 t} \\
\eta_{4 t}
\end{array}\right]
\end{aligned}
$$

where the error correction term's coefficients are represented by $\gamma_{1 t}-\gamma_{4 t}$, the homoskedastic disturbance terms are denoted by $\eta_{1 t}-\eta_{4 t}$, the error correction term is denoted by $E C M_{t-1}$. The $E C M_{t-1}$ indicates both the long run causality and the speed of adjustment to long run equilibrium, while the Wald test statistic of the first-difference of the variables shows the short run causality and its direction.

\section{Results and Discussions}

This section presents the results of the estimation and discusses the findings of the study. The descriptive statistics are presented in Table 1 with the correlation analysis of the variables used in the study. It is observed from Table 1 that the average exchange rate is approximately 91.812 while that of crude oil price is 42.918. Oil revenue is 2324.795 . The average GDP per capita is approximately $2.32 \mathrm{E}+11$. All the variables are positively skewed as indicated by the positive skewed coefficients of all the variables. The study also tested for data normality using Jaque-Bera normality test. Three variables of the study such as exchange rate, oil revenue and GDP per capita were found to be normally distributed since the P-values for Jarque-Bera test were greater than 0.05 for the variables. Only 
Table 1. Descriptive statistics and correlation results.

\begin{tabular}{ccccc}
\hline & EXC & COP & OREV & GDPC \\
\hline Mean & 91.812 & 42.918 & 2324.795 & $2.32 \mathrm{E}+11$ \\
Median & 97.017 & 28.525 & 977.635 & $1.65 \mathrm{E}+11$ \\
Maximum & 305.790 & 113.760 & 8878.970 & $4.64 \mathrm{E}+11$ \\
Minimum & 0.673 & 12.620 & 7.250 & $1.08 \mathrm{E}+11$ \\
& 76.862 & 31.993 & 2705.685 & $1.21 \mathrm{E}+11$ \\
Skewness & 0.578 & 1.125 & 0.911 & 0.791 \\
Kurtosis & 3.079 & 2.918 & 2.560 & 2.141 \\
Jarque-Bera & $2.015(0.365)$ & $7.612(0.022)$ & $5.276(0.071)$ & $4.865(0.087)$ \\
Observation & 36 & 36 & 36 & 36 \\
$\operatorname{lnEXC}_{\mathrm{t}}$ & 1.000 & & & \\
$\operatorname{lnCOP}_{\mathrm{t}}$ & 0.482 & 1.000 & & \\
$\ln _{\operatorname{lnOREV}}$ & 0.950 & 0.710 & 1.000 & 1.000 \\
$\operatorname{lnGDP}_{\mathrm{t}}$ & 0.793 & 0.834 & 0.887 & \\
\hline
\end{tabular}

Sources: Authors Computation using EViews 9; Note: Values in parentheses are the P-values.

crude oil price that is found to be not normally distributed as indicated by their $\mathrm{P}$-value of less than 0.05 . Using correlation analysis, all the variables are in natural logarithm form. All the variables have positive correlation between them and the highest approximated value of correlation is oil revenue and exchange rate which is 0.950 , followed by the GDP per capita and exchange rate and the lowest approximated value of correlation is between crude oil price and exchange rate which is 0.482 .

To examine the property of the data before conducting the estimation of the log-run model, the following are required. In the first step, we examine the non-stationarity or integration properties of the time series, using the widely used augmented Dickey-Fuller (ADF) and Philip-Perron (PP) unit root tests, in the second step, given that the variables are non-stationary. Table 2(a) presents the testing of the unit root results; exchange rate is stationary at $5 \%$ level of significance at level. Whereas crude oil price, oil revenue and Gross Domestic Products are stationary at $1 \%$ level of significance after first differencing. And using Philip Perron test all the variables are not stationary at level but became stationary after first differencing using both constant and constant with trend. Therefore, since there is a mixed of order of integration of the variables, one variable is I (0) and others are purely I (1) in the augmented dickey fuller unit root and all the variables are order of integrated of order I (1) then Autoregressive Distributed lag (ARDL) model is more efficient to be applied as an analytical tool for this research.

But coming down to Kwiatkowski Philips-Schmidt-Shin unit root test result (KPSS) as presented in Table 2(b), the decision with regard to the stationarity of the variables is the opposite of both the augmented dickey fuller unit root test 
Table 2. (a): Augmented Dickey Fuller Unit Root Test Result (ADF); (b): Kwiatkowski Philips-Schmidt-Shin Unit Root Test Result (KPSS).

(a)

\begin{tabular}{|c|c|c|c|c|c|}
\hline \multicolumn{4}{|c|}{ Level Values } & \multicolumn{2}{|c|}{ First Difference } \\
\hline Variables & Constant & $\begin{array}{l}\text { Constant } \\
\text { \& Trend }\end{array}$ & Constant & $\begin{array}{l}\text { Constant } \\
\text { \& Trend }\end{array}$ & $\begin{array}{c}\text { Order of } \\
\text { Integration }\end{array}$ \\
\hline $\operatorname{lnEXC} C_{t}$ & $-3.070^{* *}(0.038)$ & $-1.852(0.656)$ & - & - & $\mathrm{I}(0)$ \\
\hline $\operatorname{lnCOP}_{t}$ & $-1.083(0.711)$ & $-2.277(0.434)$ & $-5.562^{* * *}(0.000)$ & $-5.494^{* * *}(0.000)$ & $\mathrm{I}(1)$ \\
\hline $\operatorname{lnOREV}_{\mathrm{t}}$ & $-1.665(0.439)$ & $-0.662(0.968)$ & $-5.968^{* * *}(0.000)$ & $-5.363^{* * *}(0.000)$ & I (1) \\
\hline $\operatorname{lnGDPC}_{\mathrm{t}}$ & $0.046(0.956)$ & $-1.516(0.803)$ & $-5.126^{* * *}(0.000)$ & $-4.827^{* * *}(0.002)$ & I (1) \\
\hline
\end{tabular}

Philip Perron Unit Root Test Result (PP)

\begin{tabular}{cccccc}
\hline Variables & Constant & $\begin{array}{c}\text { Constant } \\
\text { \& Trend }\end{array}$ & Constant & $\begin{array}{c}\text { Constant } \\
\text { \& Trend }\end{array}$ & $\begin{array}{c}\text { Order of } \\
\text { Integration }\end{array}$ \\
\hline $\operatorname{lnEXC} C_{\mathrm{t}}$ & $-2.781(0.071)$ & $-1.237(0.886)$ & $-2.699^{*}(0.088)$ & $-2.824(0.202)$ & $\mathrm{I}(1)$ \\
$\operatorname{lnCOP}_{\mathrm{t}}$ & $-1.078(0.713)$ & $-2.277(0.434)$ & $-5.562^{* * *}(0.000)$ & $-5.495^{* * *}(0.000)$ & $\mathrm{I}(1)$ \\
$\operatorname{lnOREV}_{\mathrm{t}}$ & $-1.814(0.367)$ & $-0.364(0.985)$ & $-5.968^{* * *}(0.000)$ & $-7.598^{* * *}(0.000)$ & $\mathrm{I}(1)$ \\
$\operatorname{lnGDPC}_{\mathrm{t}}$ & $0.879(0.994)$ & $-2.708(0.239)$ & $-5.170^{* * *}(0.000)$ & $-4.834^{* * *}(0.002)$ & $\mathrm{I}(1)$ \\
\hline
\end{tabular}

Sources: Authors computation using EViews 9; Note: Values in parentheses are the P-values and ${ }^{* *, * *} \&^{*}$ represents statistically significant at $1 \%, 5 \% \& 10 \%$ levels.

(b)

\begin{tabular}{|c|c|c|c|c|c|}
\hline \multicolumn{4}{|c|}{ Level Values } & \multicolumn{2}{|c|}{ First Difference } \\
\hline Variables & Constant & $\begin{array}{l}\text { Constant } \\
\text { \& Trend }\end{array}$ & Constant & $\begin{array}{l}\text { Constant } \\
\text { \& Trend }\end{array}$ & $\begin{array}{l}\text { Order of } \\
\text { Integration }\end{array}$ \\
\hline $\operatorname{lnEXC}_{t}$ & $0.625^{* * *}(0.739)$ & $0.180^{* * *}(0.216)$ & 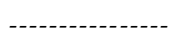 & - & $\mathrm{I}(0)$ \\
\hline $\operatorname{lnCOP}_{t}$ & $0.487^{* * *}(0.739)$ & $0.141^{* * *}(0.216)$ & ---------- & ----------- & $\mathrm{I}(0)$ \\
\hline $\operatorname{lnOREV}_{\mathrm{t}}$ & $0.659^{* * *}(0.739)$ & $0.196^{* * *}(0.216)$ & --------- & --- & $\mathrm{I}(0)$ \\
\hline $\operatorname{lnGDPC}_{t}$ & $0.678^{* * *}(0.739)$ & $0.166^{* * *}(0.216)$ & ------------ & --- & $\mathrm{I}(0)$ \\
\hline
\end{tabular}

Sources: Authors Computation Using EViews 9; Note: Values in parentheses are the Asymptotic Criticalvalues and ${ }^{* * *}$ represents statistically significant at $1 \%$ level.

and the Philip Perron unit root test. For a variable to be stationary, the Kwiatkowski Philips-Schmidt-Shin test statistic must be less than the asymptotic critical-values. Therefore, all the variables which include exchange rate, crude oil prices, oil revenue and GDP per capita are stationary at level values and at 1 percent significance level. And the Kwiatkowski Philips-Schmidt-Shin unit root test result (KPSS) contradict the results of the results of Augmented Dickey Fuller unit root test and Philip Perron unit root test as shown above were only exchange rate is stationary at level while all other variables were stationary at first difference. Therefore, even the Kwiatkowski Philips-Schmidt-Shin unit root test result (KPSS) supported the application of Autoregressive Distributed Lag (ARDL) Model.

Figure 1 presents the selection of optimal lags in autoregressive distributed 


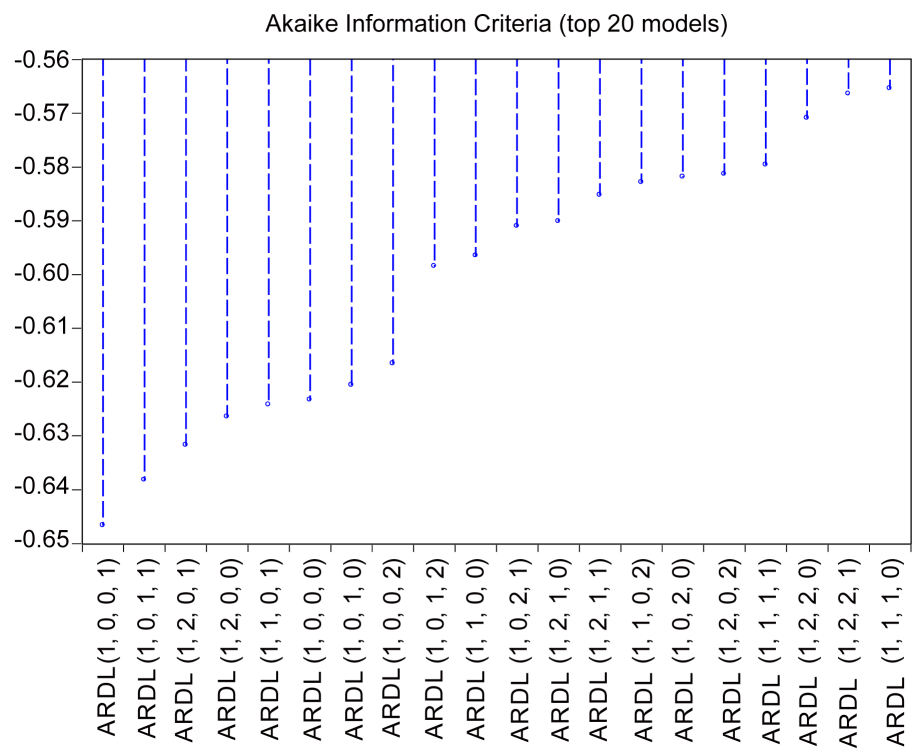

Figure 1. Optimal lag selection criteria.

lag (ARDL) model co-integration equation, based on the assumption that residuals are serially uncorrelated. The research used the most recent ARDL procedure to determine the best model. The Akaike Information Criteria (AIC) was used to detect the number of lags required in the model that is free from autocorrelation problem. The estimation found that ARDL 1, 0, 0, 1 is the optimal number of lags required in our model that is a more reliable model.

\section{Co-integration Test}

Having identified the optimum lag length, the next step was to estimate the long-run relationship among the variables by using ARDL Bounds test. The null hypothesis of no co-integration $\left(\mathrm{H}_{0}: \alpha_{1}=\alpha_{2}=\alpha_{3}=\alpha_{4}=0\right)$ was tested against the alternative hypothesis of the existence of a co-integration relationship (Ha: $\alpha_{1} \neq \alpha_{2} \neq \alpha_{3} \neq \alpha_{4} \neq 0$ ). The result of this test presented in Table 3 indicated that the null hypothesis could not be accepted for the period under study (i.e. 1983 to 2017), at $1 \%$ level of significance which is more stringent. The F-statistics (5.68) exceeded the lower bound value (4.29) and the upper bound value (5.61.) of the critical values at the aforementioned levels of significance. As such, a co-integration relationship exists in this case. Meaning the variables are moving in the same direction or that they share a common relationship in the long run.

The Johansen Juselius test for co-integration using model with Trace statistics and model with Max-Eigen value as presented in Table 4 below confirmed the existence of one co-integration equation in the trace statistics model. Therefore, we conclude that there is a long-run relationship among the dependent and independent variables and that the variables moved together in the long-run. The Johansen Juselius test for cointegration test results supported the result of ARDL bounds test for co-integration.

After establishing a co-integration relationship among the variables, the long-run model in Equation (6) and Equation (7) were estimated to obtain the 
Table 3. Bounds test result.

\begin{tabular}{cccccc}
\hline & & \multicolumn{4}{r}{ Bound test critical values } \\
\hline Model & F-stat. & Lag & $\begin{array}{c}\text { Level of } \\
\text { significance }\end{array}$ & I (0) & I (1) \\
\hline 1983 to 2017 & 5.68 & 1 & $1 \%$ & 4.29 & 5.61 \\
$\mathrm{~F}\left(\ln E X C_{t} / \ln C O P_{t}, \ln O R E V_{t} \ln G D P C_{t}\right)$ & & & $5 \%$ & 3.23 & 4.35 \\
$K=3 \& n=35$ & & $10 \%$ & 2.72 & 3.77 \\
\hline
\end{tabular}

Source: Author's Data Analysis 2020 Using Eviews 9.

Table 4. Johansen Juselius test for co-integration.

\begin{tabular}{cccccc}
\hline $\begin{array}{c}\text { Hypothesized } \\
\text { No. of CE(s) }\end{array}$ & Eigenvalue & Trace Statistic & $\begin{array}{c}0.05 \\
\text { Critical Value }\end{array}$ & $\begin{array}{c}\text { Max-Eigen } \\
\text { Statistic }\end{array}$ & $\begin{array}{c}\mathbf{0 . 0 5} \\
\text { Critical Value }\end{array}$ \\
\hline $\mathrm{C}=0$ & 0.662 & $63.581^{* * *}(0.000)$ & 47.856 & $35.869^{* * *}(0.003)$ & 27.584 \\
$\mathrm{C} \leq 1$ & 0.424 & $27.711(0.085)$ & 29.797 & $18.252(0.120)$ & 21.131 \\
$\mathrm{C} \leq 2$ & 0.189 & $9.459(0.324)$ & 15.494 & $6.928(0.497)$ & 14.264 \\
$\mathrm{C} \leq 3$ & 0.073 & $2.531(0.111)$ & 3.841 & $2.5310 .111)$ & 3.841 \\
\hline
\end{tabular}

Sources: Authors Data Analysis 2020 Using EViews 9; Note: Values in parentheses are the P-values and ${ }^{* * *}$ represent statistically significant at $5 \%$ level of significance.

long-run and short run coefficients as presented in Table 5. The results revealed that Crude oil price is negative and significant at $1 \%$ level in determining the exchange rate. Meaning that increase in crude oil price volatility by $1 \%$ depreciates the naira by approximately -1.678 percent in the long run. Precisely, a $1 \%$ increase in crude oil price will lead to $1.678 \%$ decrease in exchange rate. This is in line with the commodity currency and exchange rate theory which states that changes in terms of trade, will lead to swing in real exchange rate. This means that volatility of crude oil price exert a very strong negative impact on real foreign exchange rate in the long run. This finding is in line with the results of researchers such as [25] [26] [27] [28] [29] but contradict the results of [30] [31] [32] [33] showed that crude oil price has positive and significant impact on exchange rate.

The oil revenue is positive and significant at $1 \%$ level of significance which is also more stringent. Meaning that, $1 \%$ increase in will lead to an approximated $0.756 \%$ increase in exchange rate in the long run. Therefore, crude oil revenue brings about appreciation in the exchange rate of Naira.

The Gross Domestic Products (GDP) is also positive and significant at $1 \%$ level of significance in explaining the changes in the dependent variable. Precisely, 1 percent increase in GDP will lead to an approximated 1.380 percent increase in exchange rate in the long run. Therefore, increase in Gross Domestic Products (GDP) will brings about appreciation in the exchange rate of Naira. This finding corroborates the findings of [34] [35] [36] [37]. But contradict the findings of [38] [39] [40] [41] which showed negative relationship between GDP and 
Table 5. Estimated long run and short run coefficients.

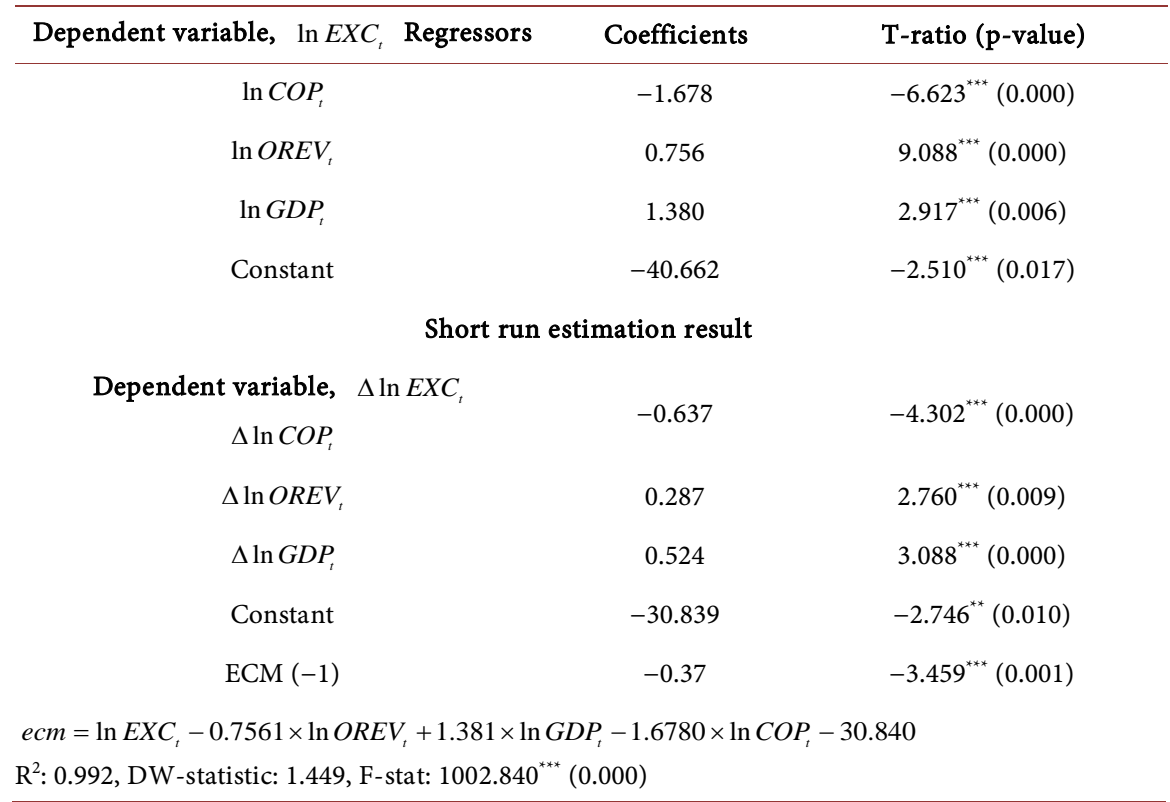

Sources: Authors Data Analysis 2020 Using EViews 9; Note. ECM = Error Correction Model. ${ }^{* * *},{ }^{* *}$, and ${ }^{*}$ are significant at $1 \%$ level.

exchange rate.

The short run results from the estimation of Equation (7) are reported in Table 5 . The crude oil price is found to be negative and significant at $1 \%$ in explaining the changes in the dependent variable. Whereas the oil revenue and gross domestic products were found to be positive and significant at $1 \%$ level of significance in explaining the changes in exchange rate in the short run. The error correction term $(-0.37)$ satisfied the econometrics requirement as it is negative, less than one and significant, which shows that the feedback or convergence rate to long-run equilibrium as $37 \%$. Precisely, the error correction term value also indicates that the long-run deviation from the exchange rate is corrected by $37 \%$ annually. The result further suggested that as oil revenue rises and gross domestic products, so also will the exchange rate of Naira appreciates in the short run, while rise in crude oil price will bring about depreciation of Naira in the short run. To show the goodness of fit of the model, R-squared, DW-statistic and F-statistics are all reported for the model in Table 5.

R-squared value of 0.99 means that 99 percent variation or changes in the dependent variable (i.e. exchange rate) can be jointly explained by the three independent variables (i.e. crude oil price, oil revenue and GPC) in the model. While only 1 percent variation in the dependent variable is explained by the factors that are not captured in the model or explained by the error term.

F-statistics value of 1002.840 with the probability value of 0.000 is positive and significant at $1 \%$ level of significance. Meaning it shows the joints significant of all the independent variables (i.e. crude oil price, oil revenue and GDP) in explaining the dependent variable. Therefore, our model is overall significant. 
Durbin Watson test-statistic value of 1.449 is below the lower standard value of 1.5 and is less than upper standard value of 2.5. Therefore, the model is may be suffering from the first order serial correlation problem and the second order serial correlation problem is subject to test.

To ensure the reliability of the estimates, diagnostic tests of serial correlation, functional form, normality and the heteroscedasticity were conducted and reported in Table 6. The results show that the null hypotheses for the serial correlation LM test, functional form and heteroscedasticity test could not be rejected except for the normality test in the model.

As suggested by Pesaran and Pesaran (1997), cumulative sum (CUSUM) and cumulative sum of squares (CUSUMSQ) tests for stability of the model along the studies were conducted. The results shown in Figure 2 and Figure 3 illustrate that the model is stable along the study period as the residual was within the critical bounds at $5 \%$ significance level.

As a robustness check to the ARDL results, we have employed dynamic DOLS, FMOLS and CCR, and their estimated results are reported in Table 7. The results showed that in all the three estimators crude oil price has a significant negative impact on exchange rate, whereas oil revenue and Gross Domestic

Table 6. The residuals of the autoregressive distributed lag diagnostic tests.

\begin{tabular}{ccc}
\hline Test statistics & LM version & F-version \\
\hline Serial correlation & CHQ $(2)=4.119[0.127]$ & $\mathrm{F}(2,28)=1.867[0.173]$ \\
Functional form & Not applicable & $\mathrm{F}(2,28)=1.734[0.195]$ \\
Normality & CHQ $(2)=6.123[0.046]^{* *}$ & Not applicable \\
Heteroscedascity & CHQ $(2)=5.975[0.201]$ & $\mathrm{F}(4,30)=1.867[0.214]$ \\
\hline
\end{tabular}

Note. The values in bracket are the probability values. $\mathrm{LM}=$ langrange multiplier test, $\mathrm{CHQ}=$ chi-square, and ${ }^{* *}$ is significant at $5 \%$ level.

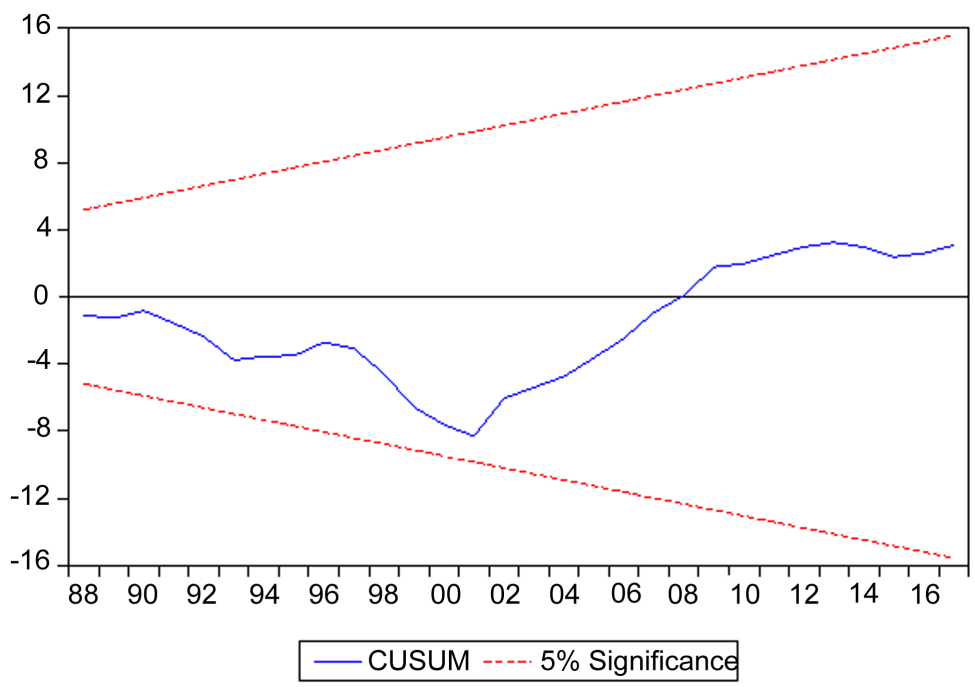

Figure 2. Plot of cumulative sum of residual for the model. 


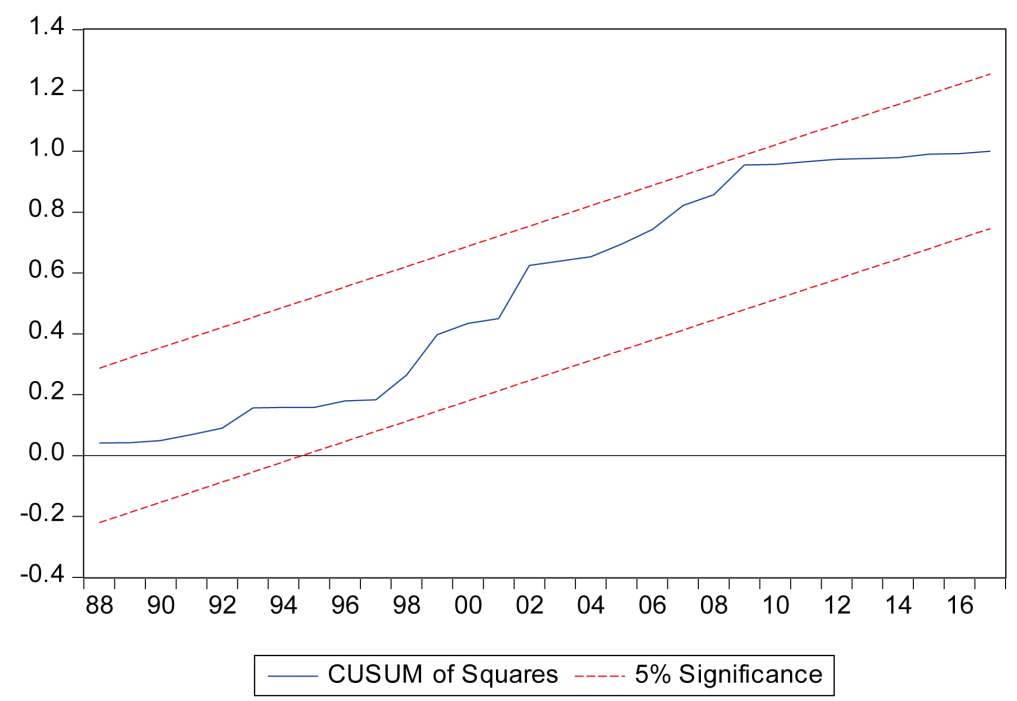

Figure 3. Plot of cumulative sum of squares for residual of the model.

Table 7. The Estimated Results for the Impact of crude oil price on Exchange rate Using DOLS, FMOL and CCR.

\begin{tabular}{cccccccc}
\hline DV $=\ln E X C_{t}:$ & \multicolumn{2}{c}{ DOLS } & FMOLS & & & CCR \\
\hline Regressors & Coefficients & SE & Coefficients & SE & Coefficients & SE \\
\hline Long-run coefficients & & & & & & & \\
Crude oil price & $-1.459^{* * *}(-7.930)$ & 0.183 & $-1.399^{* * *}(-9.481)$ & 0.147 & $-1.399^{* * *}(-8.453)$ & 0.165 \\
Oil revenue & $0.833^{* * *}(12.293)$ & 0.067 & $0.869^{* * *}(17.334)$ & 0.050 & $0.863^{* * *}(17.013)$ & 0.050 \\
GDP & $1.047^{* *}(2.632)$ & 0.397 & $0.925^{* *}(3.071)$ & 0.301 & $0.953^{* *}(2.724)$ & 0.349 \\
Constant & $-23.596^{* *}(-2.463)$ & 9.576 & $-20.930^{* * *}(-2.864)$ & 7.307 & $-21.622^{* * *}(-2.563)$ & 8.436 \\
\hline
\end{tabular}

Note. Numbers in brackets are the t-statistics. DV = Dependent variable, DOLS = dynamic ordinary least squares; FMOLS = fully modify ordinary least square; CCR = Canonical Co-integration Regression, OLS = Ordinary Least Square; SE = standard error. ${ }^{* * *} \&{ }^{* *}$ indicates significant at $1 \%$ and $5 \%$ levels of significance respectively.

Products have significant positive impact on exchange rate. Therefore, the finding substantiates the long run results of ARDL, where crude oil price is only the only variable with negative impact on exchange rate. The main focus of the study, which is crude oil price, has been revealed to impact negative and significant on exchange rate as shown by the long run ARDL results.

The next is the causal relationship between the variables was examined by employing VECM Granger causality in a vector autoregressive (VAR) system. The presence of co-integration as depicted by this study (refer to Table 3 ) suggest the existence of a causal relation in at least one direction. The estimated long run and short run causality results are presented in Table 8 and its summary in Table 9. The long run causality results reveal that $E C T_{t-1}$ in exchange rate equation is negative, less than one in value and statistically significant at $1 \%$ level. This suggests that there is a unidirectional causality running from crude oil price, oil revenue and Gross Domestic Products to exchange rate. ECT $T_{t-1}$ in equations with crude oil price and gross domestic products are negative and less 
Table 8. The results of vector error correction model granger causality.

\begin{tabular}{|c|c|c|c|c|c|}
\hline \multirow{3}{*}{$\begin{array}{l}\text { Dependent } \\
\text { Variables }\end{array}$} & \multicolumn{5}{|c|}{ Direction of causality } \\
\hline & \multicolumn{4}{|c|}{ Short run } & \multirow{2}{*}{$\begin{array}{l}\text { Long run } \\
\qquad E C T_{t-1}\end{array}$} \\
\hline & $\sum \Delta \ln E X C_{t}$ & $\sum \Delta \ln C O P_{t}$ & $\sum \Delta \ln O R E V_{t}$ & $\sum \Delta \ln G D P_{t}$ & \\
\hline$\Delta \ln E X C_{t}$ & ---- & $\begin{array}{l}3.997^{* *} \\
(0.045)\end{array}$ & $\begin{array}{c}1.541 \\
(0.214)\end{array}$ & $\begin{array}{c}0.002 \\
(0.963)\end{array}$ & $\begin{array}{c}-0.703^{* * *} \\
(0.002)\end{array}$ \\
\hline$\Delta \ln C O P_{t}$ & $\begin{array}{c}0.388 \\
(0.533)\end{array}$ & --- & $\begin{array}{c}0.220 \\
(0.638)\end{array}$ & $\begin{array}{c}0.043 \\
(0.835)\end{array}$ & $\begin{array}{l}-0.028 \\
(0.504)\end{array}$ \\
\hline$\Delta \ln O R E V_{t}$ & $\begin{array}{c}0.008 \\
(0.925)\end{array}$ & $\begin{array}{c}0.142 \\
(0.706)\end{array}$ & ---- & $\begin{array}{c}0.207 \\
(0.648)\end{array}$ & $\begin{array}{l}0.285^{* *} \\
(0.048)\end{array}$ \\
\hline$\Delta \ln G D P_{t}$ & $\begin{array}{c}1.447 \\
(0.228)\end{array}$ & $\begin{array}{c}0.512 \\
(0.474)\end{array}$ & $\begin{array}{c}0.187 \\
(0.665)\end{array}$ & --.- & $\begin{array}{l}-0.020 \\
(0.217)\end{array}$ \\
\hline Diagnostic tests & \multicolumn{5}{|c|}{$\begin{array}{l}\text { Akaike information criteria }=-0.305, \text { VEC residual serial correlation LM test }=19.680(0.234) \text {, } \\
\text { VEC White heteroskedasticity test }=98.359(0.527), \text { VEC Jarque Bera normality test }=12.719(0.121)\end{array}$} \\
\hline
\end{tabular}

Note. Values in parentheses are the P-values. LM = langrange multiplier; VEC = vector error correction ${ }^{* *}$ indicates significant at $5 \%$ level.

Table 9. The summary of the results of the vector error correction model granger causality approach.

\begin{tabular}{ccc}
\hline Direction of causality & Short run (F-statistics) & Long run $\left(E C T_{t-1}\right)$ \\
\hline $\ln C O P_{t}$ causes $\ln E X C_{t}$ & At $5 \%$ significance level & At $1 \%$ significance level \\
$\ln E X C_{t}$ causes $\ln E X C_{t}$ & NO & NO \\
$\ln G D P_{t}$ causes $\ln E X C_{t}$ & NO & NO \\
$\ln E X C_{t}$ causes $\ln C O P_{t}$ & NO & NO \\
$\ln O R E V_{t}$ causes $\ln G D P_{t}$ & NO & NO \\
$\ln G D P_{t}$ causes $\ln C O P_{t}$ & NO & NO \\
$\ln E X C_{t}$ causes $\ln O R E V_{t}$ & NO & NO \\
$\ln C O P_{t}$ causes $\ln O R E V_{t}$ & NO & NO \\
$\ln G D P_{t}$ causes $\ln O R E V_{t}$ & NO & NO \\
$\ln E X C_{t}$ causes $\ln G D P_{t}$ & NO & NO \\
$\ln C O P_{t}$ causes $\ln G D P_{t}$ & NO & \\
$\ln O R E V_{t}$ causes $\ln G D P_{t}$ & &
\end{tabular}

Source: Author's Data Analysis 2020 using Eviews 9.

than one in values but are also not significant. $E C T_{t-1}$ in oil revenue equation is less than one in value significant but is not negative. Therefore, there is no existence of long run causality among the variables because the $E C T_{t-1}$ values in the equations does not satisfy the econometrics requirement of negative, less than one in value and significant.

Beside the long run causality, the short run causality was also estimated. However, in the short run, there is a unidirectional causality from running from crude oil price to exchange rate.

The diagnostic tests' results of VECM reported in the lower part of Table 8 
show that the model is stable and reliable ass we could not reject all the null hypotheses, and therefore its estimates are acceptable for statistical inference.

\subsection{Results of Forecast Error Variance Decomposition}

The forecast error variance decomposition was used to estimate the short run dynamic properties of each of the variable originating from the shocks in the system. It is the proportion of forecast error variance for each variable that attribute to its own innovation and to innovations in the other endogenous variable. The ordering of the variables in the variance decomposition is stated in Tables 10(a)-(d) below over the same forecasting horizon for a period of five years (5).

\section{(a) Variance Decomposition of InEXC}

The variance decomposition of natural log of exchange rate (InEXC) shows that the high level of the variation experienced by InEXC is attributed to its own shock at $100 \%$ in the first period and falls to 84.074 at the end of the 5-period horizon. The contribution of the other 3 variables is quite marginal. The highest is by the natural log of crude oil price (InCOP), which contributes to $15.049 \%$ in the fifth period.

\section{(b) Variance Decomposition of InCOP}

The natural log of crude oil price (InCOP) displayed a similar pattern where its own shocks account for a disproportionate share of the total variation. The contribution of its own shock is $92.592 \%$ in the first period and falls to $89.535 \%$ in the fifth period. The contribution of the other three variables is also marginal with the natural log of exchange rate (InEXC) accounting for $8.818 \%$.

\section{(c) Variance Decomposition of InOREV}

The variance decomposition of natural log of oil revenue (InOREV) has a different pattern of low level of variation. The contribution of its own shock is about $13.476 \%$ in the first and continues to fall to $6.241 \%$ in the fifth period. The natural log of crude oil price (InCOP) maintained a high level of variation with $86.512 \%$ in the first period and continue to increase at decreasing rate up to fifth period were its account for $86.827 \%$ variation.

\section{(d) Variance Decomposition of InGDP}

The natural log of gross domestic products (InGDP) displayed a similar pattern where its own shocks account for a disproportionate share of the total variation. The contribution of its own shock is $73.185 \%$ in the first period and falls to $44.210 \%$ in the fifth period. The contribution of the other three variables is also marginal with the natural log of oil revenue (InOREV) accounting for about $11.171 \%$ variation.

In conclusion, the predominant sources of variation in the natural log of exchange rate are largely due its own shocks and innovations in natural log of crude oil prices while the predominant sources of variation in natural log of crude oil prices are due mainly to own shocks and innovations in natural log of exchange rate. Also, the predominant sources of variation in natural log of oil 
Table 10. (a): Variance Decomposition of InEXC; (b): Variance Decomposition of InCOP; (c): Variance Decomposition of InOREV; (d) Variance Decomposition of InGDP.

(a)

\begin{tabular}{cccccc}
\hline Period & S.E. & InEXC & InCOP & InOREV & InGDP \\
\hline 1 & 0.200647 & 100.0000 & 0.000000 & 0.000000 & 0.000000 \\
2 & 0.361705 & 91.83414 & 7.649416 & 0.137549 & 0.378894 \\
3 & 0.478488 & 88.21091 & 11.25563 & 0.204498 & 0.328958 \\
4 & 0.590875 & 86.64781 & 12.71043 & 0.140202 & 0.501558 \\
5 & 0.707686 & 84.07429 & 15.04907 & 0.105781 & 0.770865 \\
\hline
\end{tabular}

Source: Author's Data Using Eviews 9.

(b)

\begin{tabular}{cccccc}
\hline Period & S.E. & InEXC & InCOP & InOREV & InGDP \\
\hline 1 & 0.313397 & 7.407169 & 92.59283 & 0.000000 & 0.000000 \\
2 & 0.452623 & 6.216815 & 93.25126 & 0.257296 & 0.274633 \\
3 & 0.528486 & 7.948908 & 91.39945 & 0.223833 & 0.427811 \\
4 & 0.610140 & 8.092581 & 90.76246 & 0.215890 & 0.929073 \\
5 & 0.689176 & 8.818007 & 89.53546 & 0.511513 & 1.135024 \\
\hline
\end{tabular}

Source: Authors Data Using Eviews 9.

(c)

\begin{tabular}{cccccc}
\hline Period & S.E. & InEXC & InCOP & InOREV & InGDP \\
\hline 1 & 0.390148 & 0.011266 & 86.51231 & 13.47642 & 0.000000 \\
2 & 0.507513 & 0.071951 & 91.84128 & 8.086438 & 0.000336 \\
3 & 0.545095 & 0.337101 & 90.09112 & 7.373284 & 2.198495 \\
4 & 0.599775 & 1.039997 & 88.81164 & 6.221477 & 3.926884 \\
5 & 0.638085 & 2.954258 & 86.82705 & 6.241399 & 3.977292 \\
\hline
\end{tabular}

Source: Authors Data Using Eviews 9

(d)

\begin{tabular}{cccccc}
\hline Period & S.E. & InEXC & InCOP & InOREV & InGDP \\
\hline 1 & 0.034281 & 16.24320 & 4.862288 & 5.708951 & 73.18556 \\
2 & 0.056664 & 8.413132 & 19.57619 & 9.662178 & 62.34850 \\
3 & 0.079211 & 9.728905 & 26.00370 & 12.41099 & 51.85640 \\
4 & 0.099320 & 10.36783 & 31.14158 & 11.59129 & 46.89929 \\
5 & 0.117147 & 10.30338 & 34.31461 & 11.17160 & 44.21041 \\
\hline
\end{tabular}

Source: Authors Data Using Eviews 9.

revenue are due to shocks and innovations in natural log of crude oil prices. Similarly, the predominant sources of variation in natural log of gross domestic products are due largely to own shocks and innovations in the natural log of oil revenue. 


\subsection{Impulse Response Function Analysis}

Figure 4 illustrates the results of impulse response function analysis of exchange rate and crude oil price, natural log of oil revenue and natural log of gross domestic products in the VAR system to one standard deviation shock. When there are positive shocks to the natural log of exchange rate, the natural log of crude oil price, natural log of oil revenue and natural log of gross domestic products are found to respond negatively butt insignificant from the period one to third period. Beyond third period (i.e. year three), the negative effects of the shocks became significant until the fifth period. On the other hand when there are positive shocks to crude oil price, oil revenue and gross domestic products, the exchange rate also shows significant negative and positive responses. The results imply that the sudden increase in natural log of exchange rate and natural log of crude oil prices, natural log of oil revenue, and natural log of gross domestic product will contribute to the adverse effect to other. The estimated impulse response functions (IRFs) results showed that exchange rate responds both positive and negative way depending on time period, due to the shock of InCOP, InOREV and InGDP.

Response to Cholesky One S.D. Innovations \pm 2 S.E.
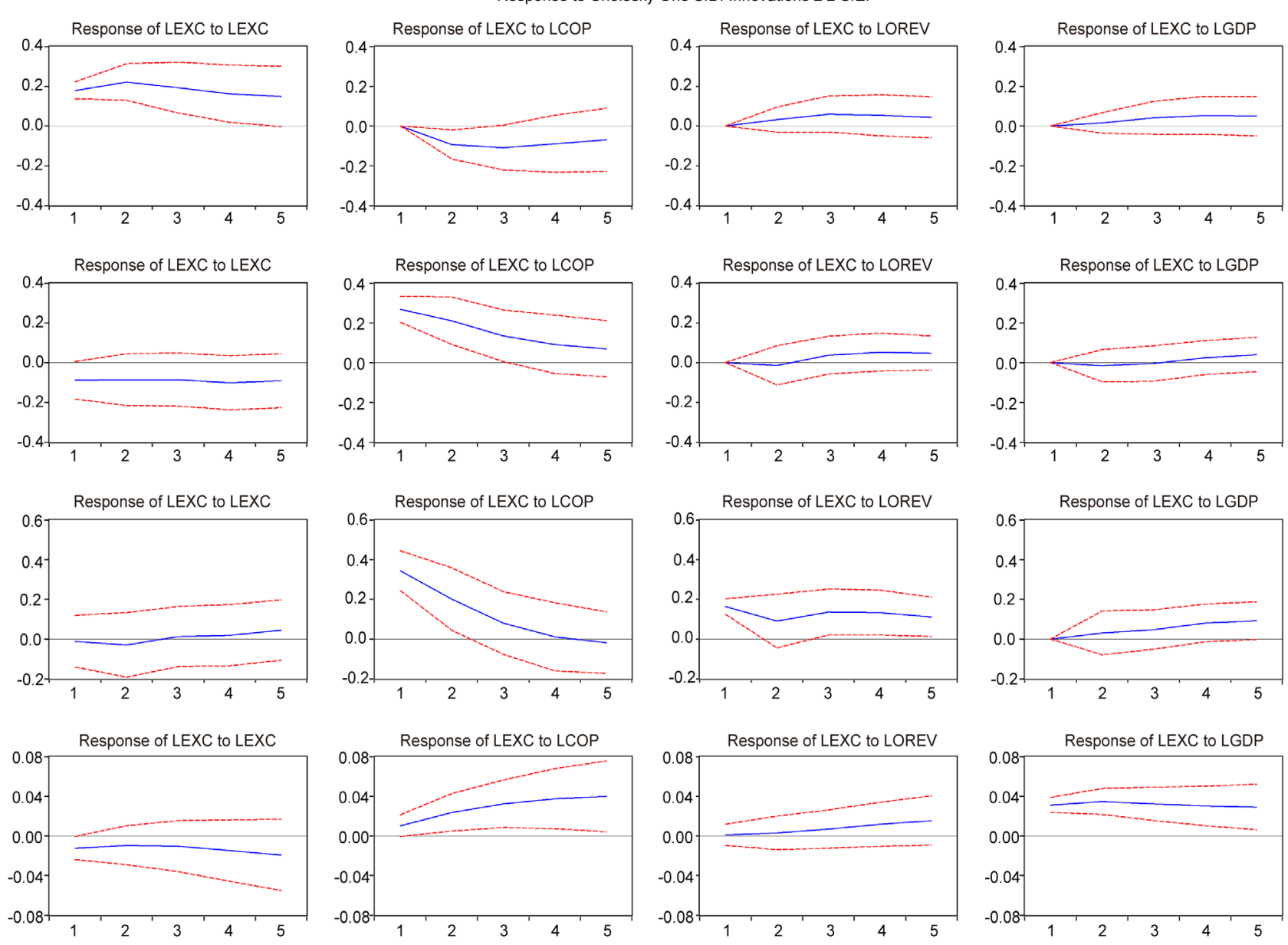

Figure 4. Impulse response function graph. 


\section{Summary and Conclusion}

This study employed an ARDL approach to co-integration to ascertain the impact of crude oil price on exchange rate in Nigeria. The impact was tested under the period of 1983 to 2017. The study employed the VECM Granger causality to test the direction of causality between the variables in both the short run and the long run. At first, this study tested for co-integration in the model after selecting the optimum lag and found that all the variables in the model were co-integrated. The long run model was also estimated and the results revealed that crude oil price has negative and significant impact on exchange rate while oil revenue and gross domestic product have positive and significant impact on exchange rate. Besides the long run model estimation, a short run model was also estimated for the model. The results also indicated that crude oil price is negative and significant in influencing exchange rate while oil revenue and gross domestic product have positive and significant impact on exchange rate. This suggests that crude oil price which is the focal point of this research, could determine the volatility in the exchange rate in both the long run and the short run. The diagnostic tests were conducted for the model, and the results revealed that the model is good fitted and has satisfied nearly all major classical linear regression requirement. The estimated impulse response functions (IRFs) results showed that exchange rate responds both positive and negative way depending on time period, due to the shock of crude oil price, oil revenue and gross domestic products. From the results of variance decomposition, the predominant sources of variation in the exchange rate are largely due to its own shocks and innovations in crude oil prices while the predominant sources of variation in crude oil prices are mainly due to own shocks and innovations in exchange rate. Also, the predominant sources of variation in oil revenue are due to shocks and innovations in of crude oil prices. Similarly, the predominant sources of variation in gross domestic products are largely due to own shocks and innovations in the oil revenue.

The robustness check was conducted using dynamic OLS, fully modified OLS and canonical co-integration regression, and their results confirmed the results of long run ARDL model. The direction of causality was equally tested using VECM Granger causality, which revealed significant causality in only exchange rate model in the long run, whereas in the short run, causality was detected also in exchange rate model.

Hence, we can conclude that international oil price, oil revenue and gross domestic products are the determinants of changes in the exchange rate in Nigeria.

\section{Conflicts of Interest}

The authors declare no conflicts of interest regarding the publication of this paper. 


\section{References}

[1] Nwanna, I.O. and Eyedayi, A.M. (2016) Impact of Crude Oil Price Volatility on Economic Growth in Nigeria. IOSR Journal of Business and Management, 8, 10-19.

[2] Hathaway, T. (2009) Oil's Importance to the World's Economy. http://www.suite101.com

[3] Mohsen, B.O. and Kandil, M. (2008) Exchange Rate Fluctuations and Output in Oil-Producing Countries: The Case of Iran. International Monetary Fund, Working Paper 07/113. https://doi.org/10.5089/9781451866773.001

[4] Ozturk, I., Feridun, M. and Kalyoncu, H. (2008) Do Oil Prices Affect the USD/YTL Exchange Rate: Evidence from Turkey. Research Paper 115/2008.

[5] Anderton, R. and Skudelny, R. (2001) Exchange Rate Volatility and Euro Area Imports. European Central Bank Working Paper Series No. 64, Frankfurt/Main.

[6] Nigeria National Petroleum Corporation (NNPC) (2018) Monthly Financial Operations Report for the Month of December 2018.

[7] Ewa, A. and Asher, O.J. (2012) The Impact of Exchange Rate Fluctuation on the Nigeria Economic Growth (1980-2010). Unpublished B.Sc. Thesis of Caritas University Emene, Emene.

[8] Ufoueze, L.O., Okuma, C.N., Nwakoby, C. and Alayekwu, U.B. (2018) Effect of Foreign Exchange Rate Fluctuation in Nigerian Economy. Economic Series Issues, 1, 105-122. https://doi.org/10.26458/1814

[9] Englama, A., Duke, O.O., Ogunleye, S. and Ismail, F.U. (2010) Oil Price and Exchange Rate Volatility in Nigeria: An Empirical Observation, Central Bank of Nigeria. Economic and Financial Review, 48, 31-42.

https://www.cbn.gov.ng/Out/2012/publications/reports/rsd/efr-2010/Economic\%20 and\%20Financial\%20Review\%20Vol\%2048\%20No\%203,\%20September\%202010/F ull\%20Text.pdf

[10] Kaushik, N., Nag, R. and Kmal, P. (2014) Oil Price and the Real Exchange Rate: The Case of India. International Business and Economics Research Journal, 13, 809-814. https://doi.org/10.19030/iber.v13i4.8688 https://clutejournals.com/index.php/IBER/article/view/8688

[11] Komain, J. (2015) Oil Price Volatility and Real Effective Exchange Rate: The Case of Thailand. International Journal of Energy Economics and Policy, 5, 574-579. http://www.econjournals.com

[12] Negi, P. (2015) Impact of Oil Price on Economic Growth: A Study of Bric Nations. Indian Journal of Accounting, 47, 144-155.

[13] Ahmad, R., Qaiser, I. and Yaseen, M. (2016) Nexus between Exchange Rate Volatility and Oil Price Fluctuations: Evidence from Pakistan. Pakistan Journal of Commerce and Social Sciences, 10, 122-148. http://www.jespk.net/publications/283.pdf

[14] Mhamad, S.H. and Saeed, S.T. (2016) Impact of Oil Price on Economic Growth: Empirical Evidence from Iraq. Journal of Economics and Sustainable Development, 7, 156-161.

[15] Ftiti, Z., Guesmi, K., Teulon, F. and Choachi, S. (2016) Relationship between Crude Oil Prices and Economic Growth in Selected OPEC Countries. Journal of Applied Business Research, 32, 11-22. https://doi.org/10.19030/jabr.v32i1.9483

[16] Apere, O.T. and Ijomah, A.M. (2013) Macroeconomic Impact of Oil Price Levels and Volatility in Nigeria. International Journal of Academic Research in Economics and Management Sciences, 2, 15-25. https://doi.org/10.6007/IJAREMS/v2-i4/48 
[17] Alley, I., Asekomeh, A., Mobolaji, H. and Adeniran, Y.A. (2014) Oil Price Shocks and Nigerian Economic Growth. European Scientific Journal, 10, 375-392.

[18] Onoja, J.A. (2015) Impact of Oil Price Volatility on the Real Exchange Rate in Nigeria: An Error Correction Model. An International Multidisciplinary Journal, Ethiopia, 9, 15-22. https://doi.org/10.4314/afrrev.v9i1.2 https://www.ajol.info/index.php/afrrev/article/view/113866/103580

[19] Egbe, O.J. (2015) The Impact of Oil Price Volatility on the Real Exchange Rate in Nigeria: An Error Correction Model. African Research Review, 9, 15-22. https://doi.org/10.4314/afrrev.v9i1.2

[20] Osuji, E. (2015) International Oil Prices and Exchange Rate in Nigeria: A Causality Analysis. International Journal of Academic Research in Economics and Management Sciences, 4, 11-22. https://doi.org/10.6007/IJAREMS/v4-i3/1798

[21] Ogboru, I., Rivi, M.T. and Idisi, P. (2017) The Impact of Changes in Crude Oil Prices on Economic Growth in Nigeria. Journal of Economics and Sustainable Development, 8, 78-89.

[22] Musa, K.S., Maijama'a, R., Shaibu, H.U. and Muhammad, A. (2019) Crude Oil Price and Exchange Rate on Economic Growth: ARDL Approach. Open Access Library Journal, 6, e5930. https://doi.org/10.4236/oalib.1105930

[23] Gummi, U.M., Buhari, A.I. and Muhammad, A. (2017) Oil Price Fluctuations and Economic Growth in Nigeria (Evidence from Granger Causality Test). Australasian Journal of Social Science, 3, 1-16. https://doi.org/10.3923/aujss.2017.1.16

[24] Sulaiman, C. and Abdur-Rahim, A.S. (2018) Population Growth and $\mathrm{CO}_{2}$ Emission in Nigeria: A Recursive ARDL Approach. Sage Open, 8, 1-14. https://doi.org/10.1177/2158244018765916

[25] Henry, J.T. (2019) Impact of Crude Oil Price Volatility on Exchange Rate in Nigeria. International Journal of Research and Innovation in Social Sciences, 3, 1-16.

[26] Ito, K. (2010) The Impact of Oil Price Volatility on Macroeconomic Activity in Russia. Economic Analysis Working Papers, No. 5, 1-10. https://www.econstor.eu/bitstream/10419/43420/1/639574653.pdf

[27] Benhabib, A., Si Mohammed, K. and Maliki, S. (2014) The Relationship between Oil Price and the Algerian Exchange Rate. Topics in Middle Eastern and African Economies, 6, 127-141.

[28] Babajide, N. and Soile, I.O. (2015) Oil Price Shocks and Nigeria's Economic Activity: Evidence from ARDL Co-Integration and VECM Analysis. https://doi.org/10.2139/ssrn.2624004

[29] Chikwe, G.C., Ujoh, C. and Uzoma, C.H. (2016) The Effect of Oil Price on Nigerian Macroeconomic Variables. International Journal of Managerial Studies and Research, 4, 13-20. https://doi.org/10.20431/2349-0349.0411002

[30] Olomola, A. (2009) Oil Price Shock and Aggregate Economic Activity in Nigeria. African Economic and Business Review, 4, 48-61. https://pdfs.semanticscholar.org/8387/9109c79e52615a338021cec526ec76505bad.pdf

[31] Adeniyi, O., Omisakin, O., Yaqub, J. and Oyinlola, A. (2012) Oil Price Price-Exchange Rate Nexus in Nigeria: Further Evidence from an Oil Exporting Country. International Journal of Humanities and Social Science, 2, 113-121. https://www.semanticscholar.org/paper/Oil-Price-Exchange-Rate-Nexus-in-Nigeria \%3A-Further-Adeniyi-Omisakin/95b7951385bb5724c232afb1478a16efb0f9e45e

[32] Buetzer, S., Habib, M.M. and Stracca, L. (2012) Global Exchange Rate Configurations: Do Oil Shocks Matter? Working Paper Series, 14(42). 
https://www.ecb.europa.eu/pub/pdf/scpwps/ecbwp1442.pdf

[33] Oluwatoyin, M.A. and Adegboye, F.B. (2014) An Analysis of the Effect of Oil Price Shock and Exchange Rate Instability on Economic Growth in Nigeria. Scottish Journal of Arts, Social Sciences and Scientific Studies, 18, 94-106. http://eprints.covenantuniversity.edu.ng/2607/1/Adegboye\%20F.\%20B.\%204.pdf

[34] Adegboyega, R.R. (2017) The Impact of Export and Import on Economic Growth in Nigeria: Evidence from VAR Approach. Journal of Management and Social Sciences, 6, 364-349.

[35] Muhammed Aslam, A.L. (2016) Impact of Exchange Rate on Economic Growth in Srilanka. World Scientific News, 54, 252-266. http://www.worldscientificnews.com

[36] Jacob, B. (2016) Impact of Exchange Rate Regimes on Economic Growth. Undergraduate Economic Review, 12, 1-22.

[37] Koirala, S. (2018) An Analysis of the Impact of Real Effective Exchange Rate on Economic Growth of Nepal. Parvaha Journal of Economic Management, 24, 206-216. https://doi.org/10.3126/pravaha.v24i1.20239

[38] Ebrahimi, S. (2011) Effects of Oil Price Shocks and Exchange Rate Volatility and Uncertainty on Economic Growth in Selective Oil Countries. Iranian Journal of Trade Studies Quarterly, 59, 83-105.

[39] Obi, K.O., Oniore, J.O. and Nnad, K.U. (2016) The Impact of Exchange Rate Regimes on Economic Growth in Nigeria. Journal of Economic and Sustainable Development, 7, 115-127. http://www.iiste.org

[40] Perpetua, U.I. (2014) Impact of Exchange Rate Variation and Inflation on Economic Growth of Nigeria: An Empirical Research Approach. Journal of Finance and Accounting, 5, 166-176. http://www.iiste.org

[41] Barguelil, A., Ben-Salha, O. and Zmami, M. (2018) Exchange Rate Volatility and Economic Growth. Journal of Economic Integration, 33, 1303-1336.

https://doi.org/10.11130/jei.2018.33.2.1302 